\title{
Slow Scholarship: Propositions for the Extended Curriculum Programme
}

\author{
Vivienne Bozalek \\ https://orcid.org/0000-0002-3212-1910 \\ Rhodes University, South Africa \\ vbozalek@gmail.com
}

\section{Abstract}

Higher education has been deeply affected by neoliberalism and corporatisation, with their emphasis on efficiency, competitiveness and valorisation of quantity over quality. This article argues that in the context of South African higher education, and in the Extended Curriculum Programme (ECP) more particularly, such commodification of education is problematic. The article explores what the Slow movement has to offer ECP in terms of scholarship. It seeks to answer the question: How might ECP be reconfigured using Slow imaginaries? Various academic disciplines and practices have incorporated Slow philosophy to develop alternative ways of doing academia; however, it has hitherto not been considered for programmes such as ECP. This article approaches Slow pedagogy for ECP using posthuman and feminist new materialist sensibilities that are predicated on a relational ontology. The article puts forward the following 10 propositions for a Slow scholarship in ECP using ideas from posthumanism and feminist new materialism: practice attentiveness through noticing, engage in responsible relations, diffract rather than reflect (thinking together affirmatively), render each other capable, enable collective responsiveness, explore creatively, making thoughts and feelings possible, enact curiosity, ask the right questions politely, foreground process rather than product, and create conditions for trust by wit(h)nessing. It is argued that by practising Slow scholarship with these propositions, ECPs might resist marketdriven imperatives that characterise contemporary academia.

Keywords: Slow scholarship; posthumanism; feminist new materialism; relational ontology; propositions; extended curriculum programme

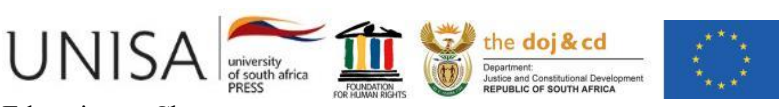

Education as Change https://unisapressjournals.co.za/index.php/EAC Volume 25 | 2021 | \#9049 | 21 pages

https://doi.org/10.25159/1947-9417/9049 ISSN 1947-9417 (Online)

(C) The Author(s) 2021 
It is not for nothing that I have been a philologist, perhaps I am a philologist still, that is to say, a teacher of slow reading [my italics]:- in the end I also write slowly. ... For philology is that venerable art which demands of its votaries one thing above all: to go aside, to take time, to become still, to become slow-it is a goldsmith's art and connoisseurship of the word which has nothing but delicate, cautious work to do and achieves nothing if it does not achieve it lento. But precisely for this reason it is more necessary than ever today, by precisely this means does it entice and enchant us the most, in the midst of an age of "work", that is to say, of hurry, of indecent and perspiring haste, which wants to "get everything done" at once, including every old or new book:this art does not so easily get anything done, it teaches to read well, that is to say, to read slowly, deeply, looking cautiously before and aft, with reservations, with doors left open, with delicate eyes and fingers. (Nietzsche [1881] 1982, 5)

\section{Introduction}

Higher education policy, practice, scholarship, research and teaching have all been deeply affected by neoliberalism and corporatisation, with their emphasis on efficiency, competitiveness and valorisation of quantity rather than quality (Braidotti 2013; Manley 2021; Smith 2017). This article proposes that putting ideas from Slow scholarship, feminist new materialism and posthumanism into conversation with one another might provide the Extended Curriculum Programme (ECP) some ways out of such marketoriented imperatives. The article explores what the Slow movement has to offer scholarship in higher education and brings in feminist new materialism and posthumanism, which includes theorists such as Karen Barad (2007, 2010, 2017a, 2017b, 2017c), Rosi Braidotti (2013), Vinciane Despret (2013, 2016), Donna Haraway (1992, 2016), Erin Manning (2009, 2012, 2016, 2020, 2021), Brian Massumi (2015), Deborah Bird Rose (2013) and Anna Tsing (2010), as well as political ethics of care theorist Joan Tronto $(1993,2013,2015)$, to develop propositions in order to enact a Slow scholarship for ECP.

The Slow movement was started by the leftist journalist, Carlo Petrini (2013), as a protest against McDonalds opening a restaurant in Rome. A Slow Food Manifesto was then developed in 1989, and initially focused on sustainability and the enjoyment of biodiversity and local food, calling for a resistance to neoliberal markets by invoking an anti-corporate agenda, emphasising qualities such as discernment, depth, pleasure and generosity.

The Slow Food movement resonated into other areas that also involved a refusal of neoliberalism, progress and the gross effects of corporatism, shifting to a focus on the quality of living. Slow scholarship has been proposed as engaging in alternative modes of doing academia and scholarship in reaction to the current modus operandi of managerialism, performance management and corporatisation of these spheres of life. This article puts Slow scholarship in conversation with posthumanism and feminist new materialism in order to develop propositions for doing ECPs differently. Feminist new materialism and posthumanism are predicated on a relational ontology, which holds that 
people and entities come into being through relationships, rather than entities' preexisting relationships. Feminist new materialism and posthumanism are based on ideas of process philosophers such as William James, Baruch Spinoza, and Alfred North Whitehead, which have been taken forward by philosophers and theorists such as Isabelle Stengers, Gilles Deleuze, Félix Guattari, Rosi Braidotti, Donna Haraway, Erin Manning and Brian Massumi. Process philosophy is concerned with relationality, creativity, and it sees the world as being in a state of constant change (Massumi 2015). The ideas of the quantum physics philosopher, Niels Bohr, which have informed the work of the queer quantum theorist, Karen Barad, and their agential realist framework, are also based on a relational ontology and have contributed significantly to feminist new materialism and posthumanism.

Feminist new materialism and posthumanism question assumptions that entities such as humans or objects are bounded, discrete and stable. These approaches challenge humancentred views of the world, the Humanist ideal of (western) Man (Braidotti 2019), as well as western, Cartesian assumptions of binary oppositions such as nature/culture, human/animal, mind/body, which are present in most social and political thought. The approaches foreground such qualities as relationality, attentiveness, responsiveness, response-ability, responsibility, curiosity, trust, and rendering one another capable. The article suggests 10 propositions using these qualities for reconfiguring and doing Slow scholarship in the ECP during coronatime.

Extended Curriculum Programmes (ECPs) were started in the early 2000s through funding by the Department of Higher Education and Training (DHET) to higher education institutions, in order to facilitate access to higher education for students who had traditionally been denied such access. These programmes are currently offered in 22 of the 26 higher education institutions in South Africa (CHE [Council on Higher Education] 2020). Universities had to submit proposals to access the funding and had to comply with criteria that incorporated 60 to 120 additional SAQA (South African Qualifications Authority) credits in tuition into accredited programmes, extending accredited programmes over a year or two years. The idea was that these programmes would augment what was already going on in degrees or accredited programmes rather than presenting stand-alone courses unrelated to programmes or disciplines. The academic departments, schools or faculties are responsible for the design of the curriculum, its assessment and quality assurance. However, in reality, in many institutions, there is still a separation between staff who teach on ECPs and mainstream lecturers. ECP lecturers are also still on contract posts in some higher education institutions, although the Council on Higher Education has made it clear that funding is assured and has encouraged institutions to make such posts permanent (CHE 2020).

In another special issue on theoretical approaches to ECPs in the journal Alternation, Garraway and Bozalek (2019) point out that much of the work on ECPs tends to be descriptive and there is a lack of theoretically informed scholarship regarding ECPs. This article is intended to contribute to this paucity in the literature by considering how 
ECPs might be reconfigured using propositions derived from posthumanism and feminist new materialism as a contribution towards a Slow scholarship. As has been noted elsewhere (see Leibowitz and Bozalek 2015), it is important for Foundational provision or ECPs to be able to embrace differences such as neurodiversity and second language speakers, and to provide conducive teaching and learning opportunities for all. ECPs need to remain vigilant that their curricula and programmes are not framed by neurotypicality ${ }^{1}$ (usually based on white, middle-class, male learning propensities with the assumption that all learning happens in a particular linear and rational way) and its related Eurocentric sensibilities and discourses, which are pervasive in the academy, and accepted as normal and given. Neurotypicality assumes that individualism is the backbone of academia, and that any need for assistance or facilitation is abnormal and should be relegated to special needs programmes, such as ECPs. Neurotypicality generally encourages accommodating difference rather than seeing difference as affirmative and essential to learning, in that it assumes that there is only one way of knowing, instead of believing that everyone can benefit from more responsive and attuned pedagogies.

What needs to be taken into account additionally is the current context in which higher education and the world in general finds itself - in the midst of the coronavirus epidemic. Since March 2020, the coronavirus has had a substantial impact on human existence, as well as all forms of education, including higher education. The virus is known to be far more virulent and deadly in communities of poor, black and indigenous people (Goldin 2021; Zaretsky 2020). Many people have lost their employment and do not have access to food and shelter during lockdown because of the pandemic (Mark 2020; Roy 2020). The pandemic has also had major implications for how higher education institutions conduct their core functions. As most universities were shut down physically, teaching had to be rearranged and moved to online platforms, and academics and students had to learn new ways of communicating with one another. Students who did not have the means to gain access to computers and the internet were disadvantaged by this process - especially those living in rural areas and townships in South Africa (Hlatshwayo, Khumalo, and Ndzimande 2021). Due to the loss of fees from foreign students, many Australian universities cut back on contract staff and many lost their jobs (Phelan and Lumb 2021). The higher education sector is still reeling from the effects of Covid-19. The virus has alerted us to the erroneous Eurocentric notions of human individualism, where disembodied, rational, unencumbered and autonomous humans are the centre of the world, but separate from it. Viruses and humans are inextricably entangled (Bozalek and Pease 2021), and humans are only one of the species in a multispecies and interconnected, relational world, where we are bound together with one another (Mbembe 2020). These humans are no longer in charge of what happens in the world and Stacy Alaimo's (2018) notion of "trans-corporeality" is a useful one for understanding a relational world in which the coronavirus is spreading.

As Manning (2021) notes, “[n]eurotypicality is not something someone is. It's a systemic baseline according to which modes of self-presentation and modes of knowing are policed". Accommodation always carries the presupposition that other ways do not exist. 
By trans-corporeality she means that "all creatures, as embodied beings, are intermeshed with the dynamic, material world, which crosses through them, transforms them, and is transformed by them" (Alaimo 2018, 435). The coronavirus, in its ability to traverse all borders, has made it plain that all species are relational and porous beings.

\section{Slow Scholarship}

Slow scholarship foregrounds values such as discernment, attentiveness, attunement, quality, depth, openness, curiosity, experimentation, pleasure, conviviality, affirmation, generosity, collectivity, process rather than product, and immanence. These values provide alternatives to the pressures and competition underlying a capitalist logic (sohn, Jang, and Jung 2015) and suggest ways in which the scholarship in ECPs can be differently enacted.

To date, a number of academic practices and disciplines have implemented and benefited from Slow scholarship. The following disciplines have been documented as enacting Slow practices: Slow archaeology (Cunningham and MacEachern 2016), Slow art (Cutcher and Irwin 2017; Lindner and Meissner 2015), Slow geography (Carr and Gibson 2017; Keighren 2017; Lane 2017), Slow journalism (Le Masurier 2019), Slow information science (Poirier and Robinson 2014), Slow medical education (Wear et al. 2015), Slow nursing (Bachmann 2011), Slow philosophy (Boulous Walker 2016), Slow science (Stengers 2018), Slow social work (Wahab, Mehrotra, and Myers 2021) and Slow sociology (Garey, Hertz, and Nelson 2014). In terms of academic practices, the following have been reported in the literature: Slow pedagogy and research (Berg and Seeber 2016; Martell 2014; Meyerhoff and Noterman 2019; O’Neill 2014; Treanor 2008), Slow critique (Badley 2020), Slow ethnography (Grandia 2015), Slow pedagogy (Collett et al. 2018; Payne and Wattchow 2009), Slow reading (Barad 2017c; Miedema 2008; Salvo 2018), Slow scholarship (Bozalek 2017; Harland et al. 2014; Hartman and Darab 2012; Leibowitz and Bozalek 2018; Meyerhoff and Noterman 2019; Mountz et al. 2015), and Slow writing (Ulmer 2017).

\section{How Can Slow Scholarship Help the Extended Curriculum Programme?}

Slow scholarship allows us to rethink time and space, which the Covid-19 pandemic has also forced those in higher education and beyond to do. Particularly now that higher education is mainly offered online in Covid conditions, we need to think about how to inhabit space and time in a meaningful way in ECPs. Slow scholarship does not necessarily mean operating at a more leisurely pace or doing substantially less, but engaging in educationally worthwhile activities, which are enriching and complex ${ }^{2}$ (Craig 2019; Parkins and Craig 2006; Treanor 2008). More particularly, ECPs need to mitigate against encouraging competitiveness among students and also staff. It is

2 Although this may seem to contradict the initial quote by Nietzsche, where he does recommend a more leisurely pace, for him Slow is also about doing things deeply and well, "with delicate eyes and fingers" (Nietzsche 1982, 5). 
important to acknowledge that higher education has been and continues to be profoundly affected by market-oriented capitalism with its logics of competitiveness, efficiency, quantity and throughput numbers, rather than a concern for accommodating gender, class, "race", neurodiversity and developing quality pedagogical ECPs. These logics generally inform higher education policies and practices, which fund throughput, and disqualify students who take longer to complete, encouraging academics to push students through instead of thoughtful and deep engagements with scholarship. ECPs can provide alternative ways of being in higher education that others can follow.

In this article, I put Slow scholarship in conversation with posthumanism and feminist new materialism, which are predicated upon a relational ontology, holding that people or entities do not pre-exist relationships, but come into being through relationships. The combination of Slow scholarship and posthumanism would mean that relationality is a central way in which Slow scholarship is enacted in ECPs. Furthermore, it would trouble the notion of the rational, autonomous, unencumbered, white, western, middle-class, male student or staff member as the normative subject and embrace difference as affirmative. Posthuman and feminist new materialists such as Karen Barad (2007, 2010, 2017a, 2017b, 2017c), Rosi Braidotti (2013, 2019), Vinciane Despret (2016), Donna Haraway (2016), Erin Manning (2009, 2012, 2016, 2020) and Brian Massumi (2015) take forward such ideas as attentiveness, attunement, response-ability, responsibility, curiosity, trust and rendering one another capable, which are useful for considering how to do pedagogies and scholarship differently in ECPs. The second part of this article works with 10 propositions for conducting Slow scholarship in ECPs that directly pertain to the ideas of these feminist posthumanists and new materialists. In the next section, I first elaborate on what is meant by propositions and then discuss each one of the 10. Slow reading and writing are used as examples of academic practices in ECP to illustrate how the propositions would work.

\section{Propositions}

Propositions are speculative ideas that help think about possibilities of how Slow scholarship might contribute to changing or reconfiguring the way ECPs are currently being conducted.

Propositions have been developed by philosophers such as Erin Manning and Brian Massumi following the work of Alfred North Whitehead (1978). According to Whitehead, propositions are different from rules; rather, they are "theories in the making" and are developed from experiences in which there is a "flash of novelty" that comes into being through appetition or desire (Manning 2009, 226). Propositions can be referred to as inflections or forces that influence what may come to be expressed in the process and how an incipient situation becomes open to be changed, intensifying or inhibiting it (Manning 2012). It is never outside the occasion or the event, but developed within it. In these propositions, it is important to bear in mind that they do not assume a volitional and intentional human agent; rather, it is in events and 
relationships, and more particularly in the in-between or interstices of what happens, that potentials come into being.

Propositions also do not make normative claims or judgements, and are not necessarily true; they move something, such as Slow scholarship, into action (Manning 2012). Propositions do not produce concrete solutions; instead they offer suggestions for what Erin Manning $(2009,226-27)$ refers to as "enabling constraints" for "thinking-inaction". As Stephanie Springgay and Sarah Truman $(2018,259)$ explain, "[p]ropositions do not give information as to how they function in concrete instances but gesture to how they could potentialize". Propositions can be thought of as worldings - "a serial iteration of the world's complexing and re-complexing, of its own relational potential" (Manning and Massumi 2020, 8).

To summarise, propositions look at what a Slow scholarship could be and ask the speculative questions: What is the new or the change that a Slow form of enquiry or scholarship, in conversation with feminist posthumanism and new materialism, could bring to its enactment in ECPs? What are interesting alternative potentialities that a Slow scholarship could activate, make possible and move students and teachers of ECP to doing things differently? In what follows, I outline 10 propositions or enabling constraints that Slow scholarship might have to offer ECPs.

\section{Practice Attentiveness through Noticing}

Attentiveness and noticing are important practices for a Slow scholarship in ECPs. These practices make it possible for things to percolate, and instil patience in waiting for things to emerge.

In order to be attentive, one needs to put aside presuppositions and one's own preoccupations and be present in the immediacy and intensities of the moment, to the myriad of ways of affecting and being affected. It also involves paying attention to other ways of being/becoming that include the human, non-human and more-than-human (Bussolini 2013). For example, Slow scholarship requires in-depth engagement with computers, books, online platforms, journals, theories, and disciplines through which students and teachers/scholars "make-with-become-with" in sympoeisis (Haraway 2016, 102).

Noticing requires finely attuned and active listening with an open attentiveness and also with discernment (Tsing 2010), so that one can establish what is important or not in scholarship - this sometimes takes some time and requires an immersion into a theoretical domain or field of enquiry.

Attentiveness and noticing involve the awakening of all our senses, activating "the sensibility of all our embodied faculties" (Lenz Taguchi 2012, 272). Slow reading requires using all one's faculties and opening oneself to the details of a text, deepening one's relationship to it, rather than immediately assuming a critical attitude to it 
(Miedema 2008). This is similar to Erin Manning's (2016) explanation of close reading in philosophy and Karen Barad's (2007) diffractive reading, which is explained in more detail in the third proposition below. A close or diffractive reading requires care-full attentiveness to a text, which is studied and stayed with, to do justice to the ideas that the author is trying to convey. This would mean for ECP that "less is more"- that instead of prescribing large amounts of texts that the students engage with superficially, peripherally or not at all, a few texts should be engaged with in-depth and justice should be done to the ideas in those texts through close and attentive readings.

\section{Engage in Responsible Relations}

Intra-acting responsibly means taking into account the entanglements of the world. Intra-action is a neologism from Barad (2007), which indicates that entities do not preexist relationships as is assumed in interaction, where they come together and are then combined. Instead, they come into being through relationships. Thus humans, nonhuman and more-than-human entities come into being through one another, in asymmetrical relationships (Haraway 2016). This asymmetry needs to be borne in mind in Slow scholarship, where there are ever-changing power differentials across positionalities and the human and non-human. For example, the social and natural sciences in ECPs occupy differential status positions in the academy, and both students and lecturers are differently valued in these fields.

Responsibility, as Barad (2007) reminds us, is not ours alone but happens in our entanglements with the world. It is also not something that is volitional or intentional, but might include actions that traverse space and time, that are non-contemporaneous and that precede us through inheritance. This is a very important consideration when decolonising the curriculum in ECP is considered. Where the curriculum comes from and is located matters a great deal, as well as whom it is set up for. Generally, the assumption is that the normative subject, whether lecturer or student, is a neurotypical, white, western, middle-class male, who has, through access to various privileges, been able to enter higher education. For ECPs in particular, it is important to be vigilant about operating from these usually hidden assumptions. Responsibility acknowledges past and present damages that have been perpetuated against those who have been marginalised - whether these are knowledges, people, disciplines - and refuses noninnocence. Responsibility means that we are all implicated and cannot extricate ourselves from what has been done in the past and present.

Responsibility or accountability in terms of Slow scholarship is never finished and is an ongoing process of checking with all involved that the activities and curriculum are working to potentialise rather than shut down abilities. Responsibility is also never confined to dualistic relationships of student/teacher; rather, it is present in multidirectional relationships in which we are entangled, including human and morethan-human others. As Barad $(2007,393)$ puts it: "Ethics is therefore not about right response to a radically exterior/ized other, but about responsibility and accountability for the lively relationalities of becoming of which we are a part." From this perspective, 
then, responsibility is never ours alone, but is part of non-contemporaneous past, present and future relationships.

In the current Covid times, we need to find new ways of engaging with one another and with teaching materials, and of inhabiting space and time differently in the move towards online learning, while thinking about how Slow scholarship can benefit us in helping learning flourish (Despret and Meuret 2016).

With regard to response-ability or the ability to respond, Deborah Bird Rose $(2013,9)$ notes that her Slow writing "is not driven in the first instance, by academic issues. It is not driven at all. It is called forth and [her] commitment is to keep faith with life by responding as best [she] can". This alerts us to the fact that Slow scholarship in ECPs needs to transcend the traditional academic curriculum and needs to be responsive to larger societal and ecological issues.

\section{Diffract Rather Than Reflect-Thinking Together Affirmatively}

Diffraction is suggested by Haraway as an alternative optical metaphor to reflection and reflexivity, as she critiques reflexivity and reflection as mirroring and producing the same elsewhere. Haraway (1992) initially defined diffraction as "a mapping of interference, not of replication, reflection, or reproduction. A diffraction pattern does not map where differences appear, but rather maps where the effects of difference appear" $(1992,300)$.

Diffraction was taken further by Barad (2007) through her interest in quantum physics, which views diffraction as a physical phenomenon that is part of wave behaviourwhether they are light, water, or sound waves. Diffraction refers to when waves "combine when they overlap and the apparent bending and spreading out of waves when they encounter an obstruction" (Barad 2007, 28). In combining, waves can either be amplified or neutralised by being superimposed upon one another. Barad uses this physical process of diffraction as a methodology that engages affirmatively with difference.

In a diffractive methodology, the details of one theory, text, oeuvre or philosophical position are read through another or others in order to come to more creative insights. It is different from comparing and contrasting this or that, and rather presents a way of "thinking insights together" (Juelskaer, Plauborg, and Adrian 2021, 123). Diffraction is different from critique, which Barad sees as a potentially epistemologically damaging process of distancing, othering and putting another theoretical or philosophical position down (Barad 2007; Juelskjær and Schwennesen 2012). Slow or immanent critique is similar to a diffractive reading in that it involves an affirmative enquiry of radical openness, choosing to appreciate and foster rather than debunk, and it also suspends judgement (Badley 2020; Manning 2021; Massumi 2015) 
Diffractive reading involves a detailed, attentive, care-full reading of one theory, approach, or text through another without foregrounding or backgrounding either, putting them into conversation with each other. In the ECPs it is important for lecturers and students to do diffractive readings together in order to come to new insights into things. It is also possible for diffractive readings to lead to inventive and generative transdisciplinary provocations. ECP lecturers might want to read texts aloud with students, so that all pay attention to the details of the text and also to role model how texts may be read through each other, in order to come to new insights.

\section{Render Each Other Capable}

The diffractive methodologies in the section above of lecturer and student reading texts together in the face-to-face or online classroom is an example of rendering each other capable, which is based on the premise that we are co-constituted through each other. Rendering each other capable is a process of enhancing the capacity or competence of all involved - the ECP scholars who are teachers, students and researchers. Here the binaries of teacher/taught, researcher/participant, lecturer/student in ECPs become redundant as it is possible for researchers to be participants and vice versa, for teachers to learn and students to teach. In other words, it is not a one-way relationship where ECP teachers/researchers render students/participants capable, but where we come into being through a multiplicity of forces and these very categories are queried through their entanglement with each other. Vinciane Despret $(2013,2016)$ has written many texts about how rendering each other capable works both between humans and non-human animals (see also Despret and Meuret 2016). Donna Haraway notes how Despret creates this same effect in her own writings about rendering each other capable:

Despret's kind of thinking enlarges, even invents, the competencies of all the players, including herself, such that the domain of ways of being and knowing dilates, expands, adds both ontological and epistemological possibilities, proposes and enacts what was not there before. That is her worlding practice. (Haraway 2016, 126-27)

\section{Enable Collective Responsiveness}

Enabling collective responsiveness or the collective ability to respond is essential for scholarship in ECP to flourish, and to be open to the variation that comes with multiple views and thoughts. This would mean being sensitive to diverse ways of being and becoming in higher education to continue learning and gaining from research relationships. It also includes encounters with reading and writing where we do not know before how and where this will lead thought, but only in retrospect. Manning (2016, ix) alerts us as to how writing and thinking are out of sync with themselves; we only know what is coming into thought afterwards or when it has begun to "make its way into the world" (2016, ix). She puts forward the idea that thinking "thickens in its encounter with futurity that orients it" $(2016$, ix). This comes about "in a gesture of encounter" $(2016$, ix) that is beyond what the reader or writer can think. We can see here that both time and space are constructed and reconstructed through our thinking with ideas of encounters in the past, present and for the future as well as here and there, 
and this is a way of thinking-with others and opening thought to new and unexpected paths. Part of the commitment to collective responsiveness is the acknowledgement of the debts we owe to others for our flourishing. We are not able to enact scholarship in our personal capacity; we are reliant on those who have preceded us, on local and international texts and theories, and on those who make it possible for us to engage in scholarship by providing for our multiple needs to flourish in various ways. Not to acknowledge this would be to fall into what Joan Tronto $(1993,2013,2015)$ would refer to as privileged irresponsibility-willful ignorance about how some benefit from the suffering of others and how the services of another contribute to one's ability to do things and maintain positions of privilege.

It is also necessary to understand how in ECPs collaborative co-participants might work across multiplicities towards the sustenance of community in contributing to and benefitting from Slow scholarship. As previously mentioned, it has also become important to pay attention to possibilities for living and dying well together in the time of the coronavirus (Haraway 2016). For example, it is distressing for loved ones not to be with one another when they are ill, dying or have passed away due to the highly infectious nature of the virus. Deborah Bird Rose's injunction to live in "the present temporalities, localities, and relationalities of our actual lives", moving towards "connection rather than fragmentation" and "ethical mutualities rather than self-interest alone" (Rose 2013, 6), contributes towards thinking of Slow scholarship in ways that enable collective responsive and response-able knowledge production.

\section{Explore Creatively-Making Thoughts and Feelings Possible}

Making and facilitating encounters for reading, making, writing, imagining, thinking, feeling and practising in inventive ways, creating new habits, would be part of doing Slow scholarship in ECP. There are some examples in a special issue on theorising ECPs that give some ideas of how this could be done (see for example Carstens 2019; Hunma et al. 2019; Romano 2019).

Exploring creatively to potentiate thoughts and feelings comes into being through Slow practices - reading, writing, researching and artwork. As Barad (2017c, 69) makes clear:

Slow reading — an arresting of thinking, at least a slowing down, moving slowly through words and sentences carefully crafted, a practice of opening up the possibilities of important insights flashing up-is an anticapitalist praxis. Not picking up a work and dismissing it or slamming it before it is given its due, before it is even understood and moving on to the next trendy theory. Critique is an indispensable practice, but there is nothing inherent in critique that makes it anticapitalist; critique too can be a handmaiden of capitalism, engaging in and enabling a continuing logic of disposability and training the mind to operate in the mode of progress, always looking to the next exciting ideas, turning aside the old in favour of the new. The possibilities for countering the economy of disposability include composting ideas, turning them over, reading against the grain, reading through, aerating the encrusted soil to stimulate new growth. 
This Slow reading requires an ability to put one's own prejudices and thoughts aside in order to do justice to the fine details of the text. These creative and affirmative approaches help develop alternative academic practices in ECPs, re-turning (composting and turning over and over) rather than teaching students to compare and contrast, which assumes an individualist logic that is implicit in colonised modes of thinking (Juelskaer, Plauborg, and Adrian 2021).

Slow scholarship is not only about challenges to capitalist and imperialist thinking. As Isabelle Stengers in an interview with Mary Zournazi reminds us, it is also about "giving a chance to the event, to the encounters which have you feeling and thinking" (Zournazi 2002, 252). This would involve an attunement to what makes it possible to do things otherwise and to find pleasure and enjoyment in the work that one is doing with students, and for academics and students also to take pleasure in their work. Slow scholarship in ECPs has the potential to create new concepts that make us think and feel in new and different ways, opening us to new modes of expression, transforming us, instead of working from tired and habitual knowledges devoid of meaning (Manning 2016, 2021).

\section{Enact Curiosity}

In terms of Slow scholarship in the ECP, cultivating curiosity as a practice means that all are changed in the process of encounters in unanticipated ways, becoming-with each other. The non-human (books, theories, physical and virtual spaces) and the human (lecturers, participants, and students) affect and are affected through their entanglements.

Cultivating curiosity means letting one's imagination go for a walk or training it to go visiting (Arendt cited in Haraway 2016, 127) and requires an openness towards the potentials in new situations, concepts and knowledge. In ECPs this would mean being discerning and vigilant with regard to situations that are maximally conducive to learning in unexpected and vitalising ways. It means that lecturers need to continue to be curious and interested about their field of knowledge, about their students and their research practices, and not assume that one knows and does not have to pay continual attention to changing circumstances. In coronatime, it means not presupposing that one knows the best ways of intra-acting with others and being open to learning new ways of doing teaching and research. This is something that Vinciane Despret, according to Haraway (2016), achieves with her whole being-both ontologically and epistemologically, rather than just with her imagination. This is because Despret finds others interesting and goes about her research not presupposing that she knows about others, instead making way for the possibility to be surprised and intrigued through unanticipated encounters.

\section{Ask the Right Questions Politely}

This proposition follows on from the previous one, which suggests that one needs to be curious and interested in the other in order to ask the right questions. It also requires a 
change of perception in the researcher/teacher as the only experts in ECP. For lecturers and researchers, it means that they need to work closely with students and research participants to understand their worlds in order to ask pertinent questions that would interest them. There would also then be a recognition of the willingness of students and research participants to engage with those who are asking questions of them, not the assumption that they are obliged to be responsive to questions. Despret (2016) emphasises the importance of researchers (and we might add ECP teachers) themselves inhabiting politeness or courtesy and showing an interest and a curiosity in what matters to the other, finding an interest in the other, and not assuming one knows this in advance from the authority of the discipline.

Asking polite questions also involves being open to the multiplicity of ways of knowing the world, including a transdisciplinary view. We learn a lot from straying out of the boundaries of the falsely bordered disciplinary areas set up in higher education (Juelskaer, Plauborg, and Adrian 2021).

Asking polite questions in ECP is another way of putting it to ECP lecturers and scholars that they need to let students and those who are being researched shape what matters to them in scholarly endeavours.

\section{Foreground Process Rather than Product}

Process philosophy, which informs feminist new materialism and posthumanism, tends to foreground process in favour of the product. This means that the process of doing research, reading, writing, and making more generally is where learning is enacted rather than in the product that may be the examination or other assessment tasks. It is in the doing that learning is happening. Moreover, collective experimentation, which occurs in teaching and research encounters in ECPs, cannot be anticipated or predicted prior to an event happening, only looked back on in retrospect. This means that learning is immanent in that it is happening in the event rather than outside of it. In her book on Slow science, Isabelle Stengers (2018) proposes that enquiry be repositioned as a process of un/learning and connection. For her, slowing down "means becoming capable of learning again, becoming acquainted with things again, reweaving the bounds of interdependency" (Stengers 2018, 81-82).

Attending to Slow principles and emphasising process in scholarship also involves "dwelling with, waiting or sitting/staying, steeping ourselves in things by re/turning, re/visiting, re/engaging, re/reading, re/writing and contemplating them anew" (Leibowitz and Bozalek 2018, 984). These ideas are reinforced in Barad's work, where she suggests "possibilities for countering an economy of disposability include composting ideas, turning them over, reading against the grain, reading through, aerating the encrusted soil to stimulate new growth" (Barad 2017b, 165). 
These practices referred to above would also mitigate against stuffing the ECP curriculum with a lot of content or large amounts of text as it would become impossible to inhabit sensibilities required for processual learning under such conditions.

\section{Create Conditions for Trust by Wit(h)nessing}

In the process of becoming-with others or in relation to others, and staying with others for extended periods of time, we create trust, learning to hold possibilities open and discovering what we might become capable of together (Despret and Meuret 2016; Tronto 2015). According to Joan Tronto (2015), trust refers to the duration of care. In times of the Covid-19 pandemic, with students and research participants, this would require what Haraway (2016) has referred to as learning how to "stay with the trouble" $(2016,2)$. We are living through challenging times, where different geopolitical spaces and groups of people are differentially affected by the virus, depending on their access to resources, including but not limited to food and caring facilities.

In this context, caring through and across time and space is where the ethical dimensions of trust and solidarity are made possible through the establishment of reiterative patterns of care in the ECP classroom and curriculum. Online spaces such as WhatsApp groups and platforms such as Zoom, as well as asynchronous modes of communication, make it possible to give and receive care in consistent ways so needed at this particular point in our history. Trust assumes an attunement with the other and a willingness to be vulnerable, with the expectation of performing actions on a continuing basis, which is important for flourishing to happen.

\section{Conclusion}

By engaging in propositions for a Slow scholarship informed by feminist new materialist and posthuman theorists and philosophers, ECPs can resist market-driven imperatives of efficiency, expediency and pressurised time frames that characterise contemporary academia. These neoliberal tendencies, which foreground throughput rather than quality education, have the effect of diminishing the academic experience for both students and lecturers, resulting in quick fixes and superficial engagement with ideas and theories. The speculative propositions for Slow scholarship that have been elaborated on in this article provide possibilities for doing ECPs differently. I hope the propositions, in providing alternative fertile courses for doing ECPs differently, have provoked otherwise thinking - thoughts previously unthinkable - to what exceeds the normative curriculum, pedagogy and scholarship. I also hope that this article has sparked the seeds of potential interest of some policymakers, teachers or students who might be open enough to take them up and put them to work in various ways in their practice. The current complexifying conditions of the coronavirus might provide the impetus to enliven relational potentials for more experimental and Slow scholarship. In this way, ECPs can take the lead and play a role in cultivating an emergence of new, affirming ways of reorienting to Slow scholarship and to reconfiguring academia differently. 


\section{Acknowledgment}

This work is based on the research supported by the National Research Foundation of South Africa (Grant Number: 120845).

\section{References}

Alaimo, S. 2018. “Trans-Corporeality”. In Posthuman Glossary, edited by R. Braidotti and M. Hlavajova, 435-38. London: Bloomsbury.

Bachmann, T. 2011. "Slow Nursing”. The American Journal of Nursing 111 (3): 12. https://doi.org/10.1097/10.1097/01.NAJ.0000395215.47519.8f.

Badley, G. F. 2020. "Essays, Essayists, and Essayism: A Slow Critique”. Qualitative Inquiry 26 (7): 806-16. https://doi.org/10.1177/1077800419830126.

Barad, K. 2007. Meeting the Universe Halfway: Quantum Physics and the Entanglement of Matter and Meaning. Durham, NC: Duke University Press. https://doi.org/10.2307/j.ctv12101zq.

Barad, K. 2010. "Quantum Entanglements and Hauntological Relations of Inheritance: Dis/continuities, Spacetime Enfoldings, and Justice-to-Come". Derrida Today 3 (2): 24068. https://doi.org/10.3366/drt.2010.0206.

Barad, K. 2017a. "No Small Matter: Mushroom Clouds, Ecologies of Nothingness, and Strange Topologies of Spacetimemattering". In Arts of Living on a Damaged Planet, edited by A. Tsing, H. Swanson, E. Gan and N. Bubandt, G103-G120. Minneapolis, MN: University of Minnesota.

Barad, K. 2017b. "Troubling Time/s and Ecologies of Nothingness: Re-turning, Remembering, and Facing the Incalculable". New Formations 92: 56-86. https://doi.org/10.3898/NEWF:92.05.2017.

Barad, K. 2017c. "What Flashes Up: Theological-Political-Scientific Fragments". In Entangled Worlds: Religion, Science and New Materialisms, edited by C. Keller and M.-J. Rubenstein, 21-88. New York, NY: Fordham University Press. https://doi.org/10.2307/j.ctt1xhr73h.4.

Berg, M., and B. K. Seeber. 2016. The Slow Professor: Challenging the Culture of Speed in the Academy. Toronto: University of Toronto Press. https://doi.org/10.3138/9781442663091.

Boulous Walker, M. 2016. Slow Philosophy: Reading against the Institution. London: Bloomsbury.

Bozalek, V. 2017. "Slow Scholarship in Writing Retreats: A Diffractive Methodology for Response-Able Pedagogies”. South African Journal of Higher Education 31 (2): 40-57. https://doi.org/10.20853/31-2-1344. 
Bozalek, V., and B. Pease. 2021. Post-Anthropocentric Social Work: Critical Posthuman and New Materialist Perspectives. London: Routledge. https://doi.org/10.4324/9780429329982.

Braidotti, R. 2013. The Posthuman. Cambridge: Polity Press.

Braidotti, R. 2019. Posthuman Knowledges. Cambridge: Polity Press.

Bussolini, J. 2013. "Recent French, Belgian and Italian Work in the Cognitive Science of Animals: Dominique Lestel, Vinciane Despret, Roberto Marchesini and Giorgio Celli”. Social Science Information 52 (2): 187-209. https://doi.org/10.1177/0539018413477938.

Carr, C., and C. Gibson. 2017. “Animating Geographies of Making: Embodied Slow Scholarship for Participant-Researchers of Maker Cultures and Material Work". Geography Compass 11 (6): e12317. https://doi.org/10.1111/gec3.12317.

Carstens, D. 2019. "New Materialist Perspectives for Pedagogies in Times of Movement, Crisis and Change". Alternation 26 (2): 138-60. https://doi.org/10.29086/25195476/2019/v26n2a7.

CHE (Council on Higher Education). 2020. "Extended Programmes with an Integrated Foundation Phase: Theoretical Considerations for Curriculum Design". In Briefly Speaking, 14. Pretoria: Council on Higher Education.

Collett, K. S., C. L. Van den Berg, B. Verster, and V. Bozalek. 2018. "Incubating a Slow Pedagogy in Professional Academic Development: An Ethics of Care Perspective". In "The Ethics of Care and Academic Development", edited by V. Bozalek and C. Winberg, special issue, South African Journal of Higher Education 32 (6): 117-36. https://doi.org/10.20853/32-6-2755.

Craig, G. 2019. "Reclaiming Slowness in Journalism: Critique, Complexity and Difference". In Slow Journalism, edited by M. Le Masurier, 23-35. London: Routledge. https://doi.org/10.4324/9780429469725-3.

Cunningham, J. J., and S. MacEachern. 2016. "Ethnoarchaeology as Slow Science”. World Archaeology 48 (5): 628-41. https://doi.org/10.1080/00438243.2016.1260046.

Cutcher, A. L., and R. L. Irwin. 2017. "Walkings-through Paint: A C/a/r/tography of Slow Scholarship". Journal of Curriculum and Pedagogy 14 (2): 116-24. https://doi.org/10.1080/15505170.2017.1310680.

Despret, V. 2013. "Responding Bodies and Partial Affinities in Human-Animal Worlds". Theory, Culture and Society 30 (7-8): 51-76. https://doi.org/10.1177/0263276413496852.

Despret, V. 2016. What Would Animals Say If We Asked the Right Questions? Minneapolis, MN: University of Minnesota Press. https://doi.org/10.5749/minnesota/9780816692378.001.0001. 
Despret, V., and M. Meuret. 2016. "Cosmoecological Sheep and the Arts of Living on a Damaged Planet”. Environmental Humanities 8 (1): 24-36. https://doi.org/10.1215/22011919-3527704.

Garey, A., R. Hertz, and M. K. Nelson, eds. 2014. Open to Disruption: Time and Craft in the Practice of Slow Sociology. Nashville, TN: Vanderbilt University Press.

Garraway, J., and V. Bozalek. 2019. "Theoretical Frameworks and the Extended Curriculum Programme”. Alternation 26 (2): 8-35.

Goldin, I. 2021. Rescue: From Global Crisis to a Better World. London: Sceptre.

Grandia, L. 2015. "Slow Ethnography: A Hut with a View". Critique of Anthropology 35 (3): 301-17. https://doi.org/10.1177/0308275X15588616.

Haraway, D. 1992. "The Promises of Monsters: A Regenerative Politics for Inappropriate/d Others". In Cultural Studies, edited by L. Grossberg, C. Nelson and P. A. Treichler, 295337. New York, NY: Routledge.

Haraway, D. 2016. Staying with the Trouble: Making Kin in the Chthulucene. Durham, NC: Duke University Press. https://doi.org/10.2307/j.ctv11cw25q.

Harland, T., A. McLean, R. Wass, E. Miller and K. Nui Sim. 2014. “An Assessment Arms Race and Its Fallout: High-Stakes Grading and the Case for Slow Scholarship". Assessment and Evaluation in Higher Education 40 (4): 528-41. https://doi.org/10.1080/02602938.2014.931927.

Hartman, Y., and S. Darab. 2012. "A Call for Slow Scholarship: A Case Study on the Intensification of Academic Life and Its Implications for Pedagogy". In "A Scholarly Affair: Activating Cultural Studies", edited by R. Garbutt and B. Offord, special issue, Review of Education, Pedagogy and Cultural Studies 34 (1-2): 49-60. https://doi.org/10.1080/10714413.2012.643740.

Hlatshwayo, M. N., S. D. Khumalo, and N. Ndzimande. 2021. "The Pandemic Is Our Portal: Re-Imagining Teaching and Learning in the Time of Covid-19". African Perspectives of Research in Teaching and Learning 5 (1): 59-77.

Hunma, A., M. Arend, G. Nomdo, C. Hutchings, and S. Samson. 2019. "Revisiting Writer Identities in Discomforting Spaces: The Envisioned Self in Writing". Alternation 26 (2): 89-116. https://doi.org/10.29086/2519-5476/2019/v26n2a5.

Juelskjær, M., and N. Schwennesen. 2012. "Intra-Active Entanglements: An Interview with Karen Barad”. Kvinder, Koen og Forskning 12 (1-2): 10-23. https://doi.org/10.7146/kkf.v0i1-2.28068.

Juelskaer, M., H. Plauborg, and S. W. Adrian. 2021. Dialogues on Agential Realism: Engaging in Worldings through Research Practice. London: Routledge. https://doi.org/10.4324/9780429056338. 
Keighren, I. M. 2017. "History and Philosophy of Geography I: The Slow, the Turbulent, and the Dissenting". Progress in Human Geography 41 (5): 638-47. https://doi.org/10.1177/0309132516653285.

Lane, S. N. 2017. "Slow Science, the Geographical Expedition, and Critical Physical Geography”. The Canadian Geographer/Le Géographe Canadien 61 (1): 84-101. https://doi.org/10.1111/cag.12329.

Le Masurier, M. 2019. "Slow Journalism: An Introduction to a New Research Paradigm". In Slow Journalism, edited by M. Le Masurier, 1-9. London: Routledge. https://doi.org/10.4324/9780429469725-1.

Leibowitz, B., and V. Bozalek. 2015. "Foundation Provision-A Social Justice Perspective". South African Journal of Higher Education 29 (1): 8-25. https://doi.org/10.20853/29-1447.

Leibowitz, B., and V. Bozalek. 2018. "Towards a Slow Scholarship of Teaching and Learning in the South". Teaching in Higher Education 23 (8): 981-94. https://doi.org/10.1080/13562517.2018.1452730.

Lenz Taguchi, H. 2012. "A Diffractive and Deleuzian Approach to Analysing Interview Data". Feminist Theory 13 (3): 265-81. https://doi.org/10.1177/1464700112456001.

Lindner, C., and M. Meissner. 2015. "Slow Art in the Creative City: Amsterdam, Street Photography, and Urban Renewal". Space and Culture 18 (1): 4-24. https://doi.org/10.1177/1206331213509914.

Manley, S. 2021. "On Holistic Academic Development in a Pandemic (in Verse)". International Journal for Academic Development 1-7. https://doi.org/10.1080/1360144X.2021.1990065.

Manning, E. 2009. Relationscapes: Movement, Art, Philosophy. Cambridge, MA: The MIT Press. https://doi.org/10.7551/mitpress/9780262134903.001.0001.

Manning, E. 2012. Always More than One: Individuation's Dance. Durham, NC: Duke University Press. https://doi.org/10.1515/9780822395829.

Manning, E. 2016. The Minor Gesture. Durham, NC: Duke University Press. https://doi.org/10.2307/j.ctv111jhg1.

Manning, E. 2020. For a Pragmatics of the Useless. Durham, NC: Duke University Press. https://doi.org/10.1515/9781478012597.

Manning, E. 2021. "Neuroatypicality". Presented as part of the webinar series Doing Academia Differently: In Conversation with Neuroatypicality, hosted by the University of Missouri, the University of the Western Cape and Ghent University, October 2021-July 2022. Accessed December 7, 2021. https://www.youtube.com/watch?v=dcaCx83aj-0. 
Manning, E., and B. Massumi. 2020. "For a Whiteheadian Laboratory: How Do You Make Yourself a Proposition?" In Propositions in the Making: Experiments in a Whiteheadian Laboratory, edited by R. Faber, M. Halewood and A. M. Davis, 3-18. New York, NY: Lexington Books. https://doi.org/10.1515/9781478021964-025.

Mark, S. O. 2020. "Fuck the Bread. The Bread Is Over". The Paris Review May 7, 2020. Accessed December 6, 2021. https://www.theparisreview.org/blog/2020/05/07/fuck-thebread-the-bread-is-over/.

Martell, L. 2014. "The Slow University: Inequality, Power and Alternatives". Forum: Qualitative Social Research 15 (3): article 10. Accessed January 26, 2021. http://www.qualitative-research.net/index.php/fqs/article/view/2223/3692/.

Massumi, B. 2015. Politics of Affect. Cambridge: Polity Press.

Mbembe, A. 2020. "The Universal Right to Breathe". Translated by C. Sheard. In the Moment (blog), Critical Inquiry, April 13, 2020. Accessed December 6, 2021.

https://critinq.wordpress.com/2020/04/13/the-universal-right-to-breathe/.

Meyerhoff, E., and E. Noterman. 2019. "Revolutionary Scholarship by Any Speed Necessary: Slow or Fast But for the End of this World". ACME: An International Journal for Critical Geographies 18 (1): 217-45. https://acme-journal.org/index.php/acme/article/view/1429.

Miedema, J. 2008. Slow Reading. Duluth, MN: Litwin Books.

Mountz, A., A. Bonds, B. Mansfield, J. Loyd, J. Hyndman, M. Walton-Roberts, R. Basu, R. Whitson, R. Hawkins, T. Hamilton, and W. Curran. 2015. "For Slow Scholarship: A Feminist Politics of Resistance through Collective Action in the Neoliberal University". ACME: An International Journal for Critical Geographies 14 (4): 1235-259. Accessed December 7, 2021. https://www.acme-journal.org/index.php/acme/article/view/1058.

Nietzsche, F. (1881) 1982. Daybreak. Translated by R. J. Hollingdale. Cambridge: Cambridge University Press.

O’Neill, M. 2014. "The Slow University_Work, Time and Well-Being”. Forum: Qualitative Social Research 15 (3): article 14. https://doi.org/10.17169/fqs-15.3.2226.

Parkins, W., and G. Craig. 2006. Slow Living. Oxford: Berg.

Payne, P. G., and B. Wattchow. 2009. "Phenomenological Deconstruction, Slow Pedagogy, and the Corporeal Turn in Wild Environmental/Outdoor Education". Canadian Journal of Environmental Education 14: 15-32. https://cjee.lakeheadu.ca/article/view/883.

Petrini, C. 2013. Slow Food Nation: Why Our Food Should be Good, Clean, and Fair. New York, NY: Rizzoli Publications. 
Phelan, L., and M. Lumb. 2021. "Higher Education for Times of Climate Crisis - Critical Awareness, Purpose and Community". International Studies in Sociology of Education 30 (1-2): 173-90. https://doi.org/10.1080/09620214.2020.1854828.

Poirier, E., and L. Robinson. 2014. "Slow Delphi: An Investigation into Information Behaviour and the Slow Movement". Journal of Information Science 40 (1): 88-96. https://doi.org/10.1177/0165551513506360.

Romano, N. 2019. "Just(ice) Do It! Re-membering the Past through Co-Affective Aesthetic Encounters with Art/ History”. Alternation 26 (2): 62-88. https://doi.org/10.29086/2519$5476 / 2019 / \mathrm{v} 26 \mathrm{n} 2 \mathrm{a} 4$.

Rose, D. B. 2013. "Slowly-Writing into the Anthropocene". In "Writing Creates Ecology and Ecology Creates Writing”, edited by M. Harrison, D. B. Rose, L. Shannon and K. Satchel, special issue, TEXT 20 (1): 1-14. https://doi.org/10.52086/001c.28826.

Roy, A. 2020. "We Need a Reckoning”. Vimeo video, 5:40. Accessed December 6, 2021. https://vimeo.com/426871719?ref=fb-share.

Salvo, J. 2018. "Slow Reading: Reflections on Jasmine Ulmer's 'Writing Slow Ontology”, Qualitative Inquiry 26 (7): 790-97. https://doi.org/10.1177/1077800418808540.

Smith, J. 2017. "Target-Setting, Early-Career Academic Identities and the Measurement Culture of UK Higher Education". In "Academic Life in the Measured University: Pleasures, Paradoxes and Politics", edited by T. Peseta, S. Barrie and J. McLean, special issue, Higher Education Research and Development 36 (3): 597-611. https://doi.org/10.1080/07294360.2017.1288708.

sohn, d., H.-J. Jang, and T. Jung. 2015. Go Slow and Curvy: Understanding the Philosophy of the Cittaslow Slow City Phenomenon. New York, NY: Springer. https://doi.org/10.1007/978-3-319-14854-0.

Stengers, I. 2018. Another Science Is Possible. A Manifesto for Slow Science. Cambridge: Polity Press.

Treanor, B. 2008. "Slow University: A Manifesto". Accessed August 20, 2018. http://faculty.lmu.edu/briantreanor/slow-university-a-manifesto/.

Tronto, J. C. 1993. Moral Boundaries: A Political Argument for an Ethic of Care. New York, NY: Routledge.

Tronto, J. C. 2013. Caring Democracy: Markets, Equality and Justice. New York, NY: New York University Press.

Tronto, J. C. 2015. Who Cares? How to Reshape a Democratic Politics. Ithaca, NY: Cornell University Press. https://doi.org/10.7591/cornell/9781501702747.001.0001. 
Springgay, S., and S. E. Truman. 2018. Walking Methodologies in a More-than-Human World: WalkingLab. London: Routledge.

Tsing, A. L. 2010. “Arts of Inclusion, or How to Love a Mushroom”. Manoa 22 (2): 191-203.

Ulmer, J. B. 2017. “Writing Slow Ontology”. Qualitative Inquiry 23 (3): 201-11. https://doi.org/10.1177/1077800416643994.

Wahab, S., G. R. Mehrotra, and K. E. Myers. 2021. "Slow Scholarship for Social Work: A Praxis of Resistance and Creativity". Qualitative Social Work 1-13. https://doi.org/10.1177/1473325021990865.

Wear, D., J. Zarconi, A. Kumagai, and K. Cole-Kelly. 2015. "Slow Medical Education". Academic Medicine 90 (3): 289-93. https://doi.org/10.1097/ACM.0000000000000581.

Whitehead, A. N. 1978. Process and Reality. New York, NY: Free Press.

Zaretsky, Z. 2020. "Culling the Herd: A Modest Proposal”. London Review of Books, May 14, 2020. Accessed December 6, 2021. https://www.lrb.co.uk/blog/2020/may/culling-the-herda-modest-proposal.

Zournazi, M. 2002. Hope: New Philosophies for Change. Sydney: Pluto Press. 